\title{
The influence of heat stress on energy metabolism in Simmental dairy cows during the periparturient period
}

\author{
Romana Turk ${ }^{1 *}$, Nikola Rošíc 2 , Silvijo Vince ${ }^{3}$, Sonja Perkov, Marko Samardžija ${ }^{3}$, Blanka \\ Beer-Ljubićs, Maja Belić ${ }^{1}$, and Mirna Robić ${ }^{1}$ \\ ${ }^{1}$ Department of Pathophysiology, Faculty of Veterinary Medicine, University of Zagreb, Zagreb, Croatia \\ ${ }^{2}$ Veterinary Practice Jastrebarsko d.o.o., Jastrebarsko, Croatia \\ ${ }^{3}$ Department for Reproduction and Obstetrics, Faculty of Veterinary Medicine, University of Zagreb, \\ Zagreb, Croatia \\ ${ }^{4}$ Department of Medical Biochemistry and Laboratory Medicine, Merkur University Hospital, Zagreb, Croatia \\ ${ }^{5}$ Clinic for Internal Diseases, Faculty of Veterinary Medicine, University of Zagreb, Zagreb, Croatia
}

TURK, R., N. ROŠIĆ, S. VINCE, S. PERKOV, M. SAMARDŽIJA, B. BEER-LJUBIĆ, M. BELIĆ, M. ROBIĆ: The influence of heat stress on energy metabolism in Simmental dairy cows during the periparturient period. Vet. arhiv 90, 1-10, 2020.

\section{ABSTRACT}

Heat stress adversely affects the metabolism and production of dairy cows, particularly during the transition period. The aim of this study was to evaluate energy metabolism in heat stressed dairy cows during the periparturient period. Twenty-four Simmental dairy cows were included in the study. The cows were assigned into two groups according to the season: the summer group $(\mathrm{n}=12)$ and autumn group $(\mathrm{n}=12)$. Physiological parameters (rectal temperature, respiratory and heart rate) and serum metabolic parameters (glucose, triglycerides, total cholesterol, high-density lipoprotein cholesterol (HDL-C), non-esterified fatty acids (NEFA) and beta-hydroxy butyrate (BHB) were measured at days $-21,-7,8,16,24,32$ and 40 relative to calving. There were no significant differences in glucose concentration between the investigated groups $(\mathrm{P}<0.05)$. Serum NEFA concentration was significantly higher $(\mathrm{P}<0.05)$ in the summer group before calving at day -7 , while after calving it was significantly lower $(\mathrm{P}<0.05)$ at days 16 and 32 of lactation compared to the autumn group. The summer group had lower BHB concentrations after calving compared to the autumn one with statistical significance at days 8,16 and 24 postpartum $(\mathrm{P}<0.05)$. Lipid parameters were also significantly lower $(\mathrm{P}<0.05)$ in the summer group after calving, particularly total cholesterol and HDL-C at days $16,24,32$ and 40 postpartum. The results indicate that changes in energy metabolism in dairy cows under heat stress are directed to reduce NEFA oxidation, in order to limit metabolic heat production. These metabolic adaptations mostly occur after calving because dairy cows are more susceptible to heat stress in early lactation as they produce more metabolic heat during milk production.

Key words: heat stress; dairy cows; lipid mobilisation; non-esterified fatty acids; beta-hydroxy butyrate

\footnotetext{
*Corresponding author:

Romana Turk, PhD, Faculty of Veterinary Medicine, University of Zagreb, Heinzelova 55, Zagreb, Croatia, Phone: +385 12390 180; E-mail: rturk@vef.hr
} 


\section{Introduction}

Climate changes and global warming greatly affect the performance and production of dairy cows, and are having a significant impact on the dairy industry. Elevated ambient temperature is one of the recognized environmental factors contributing to disturbances in the general health and production of dairy cows. In these conditions, dairy cows produce a large amount of metabolic heat and accumulate additional heat, leading to raised body temperature. Exposure to heat stress decreases feed intake and thus alters their metabolism and hormonal balance, compromises lactation and reproductive performance and increases disease incidence (WEST, 2003). Traditionally, it has been assumed that heat stress has an indirect effect on bovine production, particularly milk yield, by the reduction in feed intake. However, recent studies have demonstrated that heat stress might have a direct influence on the systemic metabolism, affecting cellular physiology (RHOADS et al., 2009; WHEELOCK et al., 2010).

The transition period is critical for a cow's health and production, even in normal environmental conditions. Nutrient demands during the transition period dramatically change in order to meet the energy (glucose and amino acids) and mineral requirements needed for the gravid uterus in late gestation and for the mammary gland at the beginning of lactation. These demands are maintained by metabolic adaptations in glucose, fatty acid, and mineral metabolism (BELL, 1995). Increased glucose requirements during late pregnancy and the even greater requirements of the mammary gland during lactation demand an adjustment between glucose synthesis and its utilization in the peripheral tissues such as the maternal liver, adipose tissue, skeletal muscles and other tissues (BELL and BAUMAN, 1997). The adaptation of glucose metabolism is supported by increased gluconeogenesis from propionate, amino acids from protein degradation and glycerol released during lipolysis (REYNOLDS et al., 2003). Hepatic gluconeogenesis is increased during late pregnancy and early lactation to supply uterine and mammary demands. Simultaneously, glucose utilisation by adipose tissue and skeletal muscles is reduced (BELL and BAUMAN, 1997). Glucose is the main substrate for lactose synthesis by the mammary gland during lactation (GUINARDFLAMENT et al., 2006).

In early lactation, high nutrient demands for lactogenesis usually exceed nutrient intake, resulting in a negative energy balance (NEB) with a marked lipid mobilization from adipose tissue to support milk production (DRACKLEY et al., 2001). Lipid mobilisation during NEB is accompanied by increased non-esterified fatty acid (NEFA) concentration in the blood. NEFA is metabolised in the liver by $\beta$-oxidation to acetyl-coenzyme A (acetyl-CoA) that enters the tricarboxylic acid (TCA) cycle to produce energy. Excessive amounts of acetyl-CoA are converted by ketogenesis to acetoacetate, and subsequently to acetone and betahydroxybutyrate (BHB), providing a significant source of energy for transitioning dairy cows (WHEELOCK et al., 2010). Both NEFA and BHB are considered as good markers of excessive NEB and lipomobilisation syndrome (CHAPINAL et al., 2011). A recent paper by MARCO RAMELL et al. (2016) reviewed the potential of proteomic techniques, to search for new biomarkers related to NEB and fatty liver syndrome. Heat stress may further aggravate the adverse effects of NEB, and trigger more serious disorders and systemic inflammation. Thus, proper nutritional management of a periparturient cow is crucial to support metabolic adaptation and to avoid metabolic diseases as much as possible.

The aim of this study was to evaluate energy metabolism in heat stressed dairy cows during the periparturient period.

\section{Materials and methods}

Animals and experimental design. Twenty-four Simmental dairy cows were included in the study. The cows were assigned into two groups according to the season: the summer group $(\mathrm{n}=12)$ consisted of cows with calving time during the summer (June, July, and August), and the autumn group $(\mathrm{n}=12)$ consisted of cows that calved during the autumn (October, November and December). The cows were housed on a private dairy farm in Zagreb County, in a partially open free-stall barn with a 
ventilation opening on the roof to provide fresh air and to remove excess moisture and heat.

Air temperature and relative humidity in the stall were recorded at each blood sampling, using a multi-function climate-measuring instrument (Testo 445, Melrose, MA, USA). From the recorded data, a temperature-humidity index (THI) was calculated according to the equation (NRC, 1971):

$\mathrm{THI}=(1.8 \times \mathrm{T}+32)-[(0.55-0.0055 \times \mathrm{RH}) \times(1.8 \times \mathrm{T}-26.8)]$ where

$\mathrm{T}=$ temperature; $\mathrm{RH}=$ relative humidity

Sample collection and laboratory analyses. Blood samples were collected from the $v$. coccygea into Vacutainer tubes without any anticoagulant, and containing a clot activator, at seven time points: 21 and 7 days before calving and 8, 16, 24, 32 and 40 days after calving. After clotting for two hours at room temperature, the Vacutainer tubes were centrifuged at $3000 \mathrm{~g}$ for $30 \mathrm{~min}$ at room temperature. The sera were separated, aliquoted and stored at $-80^{\circ} \mathrm{C}$. The heart and respiratory rates and rectal temperature were recorded at each sampling time.

Glucose concentration and lipid parameters (triglycerides, total cholesterol and HDLcholesterol) were measured by commercial kit reagents (Beckman Coulter Biomedical Ltd., Ireland) on a Beckman Coulter AU 680 biochemical analyser (Beckman Coulter Biomedical Ltd., Ireland). Beta-hydroxy butyrate (BHB) and nonesterified fatty acids (NEFA) were analysed by commercial kits (Randox, Ireland) on a Beckman Coulter AU 640 biochemical analyser (Beckman Coulter Biomedical Ltd., Ireland).

Statistical analysis. Statistical analysis of the data was performed using SAS 9.4 software (Statistical Analysis Software 2002-2012 by SAS Institute Inc., Cary, USA). Normal data distribution was tested using the PROC TRANSREG module. When the presumptions of normal distribution of the analysed dependent variables were disturbed, and in cases of heteroscedasticity of variances, transformation of the variables was performed by log or exponential transformation. A quick test of dependent variables was performed by multivariance analysis of variance, based on the criterion of Wilks' lambda, using the GLM procedure. The main model was performed by the mixed module (PROC MIXED) and included the fixed effects of the group, period and their interaction. The random effect of an animal with repeating measurements (animal identification number) over time was included in the model. The decisions of which type of variance-covariance structure would be used in the model were based on the SAS criteria for evaluating model fitting (AIC and BIC). The multiple comparison test of the least-square means, with Tukey's correction, was performed using the SLICE option, to compare each group level within the period. The level of statistical significance was set at $\mathrm{P}<0.05$. The results were expressed as least squares means (LSM) and standard error of the mean. After analysis, if transformation was performed, the data were reversed to their original values.

\section{Results}

Rectal temperature, heart and respiratory rate and temperature-humidity index. Rectal temperature $\left({ }^{\circ} \mathrm{C}\right)$ was significantly increased $(\mathrm{P}<0.05)$ in the summer group at days $-21,-7,8,16$, 24 and 32 relative to calving compared to the cows in the autumn group, while there was no significant difference at day 40 after calving (Fig. 1).

In accordance with this, the respiratory rate was significantly increased $(\mathrm{P}<0.001)$ in the cows in the summer at days $-7,8,16,24,32$ and 40 in comparison to the cows in the autumn (Fig. 2).

Heart rate was increased in the summer period compared to the autumn group, with statistical significance $(\mathrm{P}<0.05)$ at $16^{\text {th }}$ day of lactation (Fig. $3)$.

The temperature-humidity index (THI) was significantly higher $(\mathrm{P}<0.05)$ in the summer group (78.90 \pm 0.54$)$ compared to the cows in the autumn $(58.6 \pm 0.75)$ indicating mild to moderate heat stress in cows during the summer (ARMSTRONG, 1994), Fig. 4. 


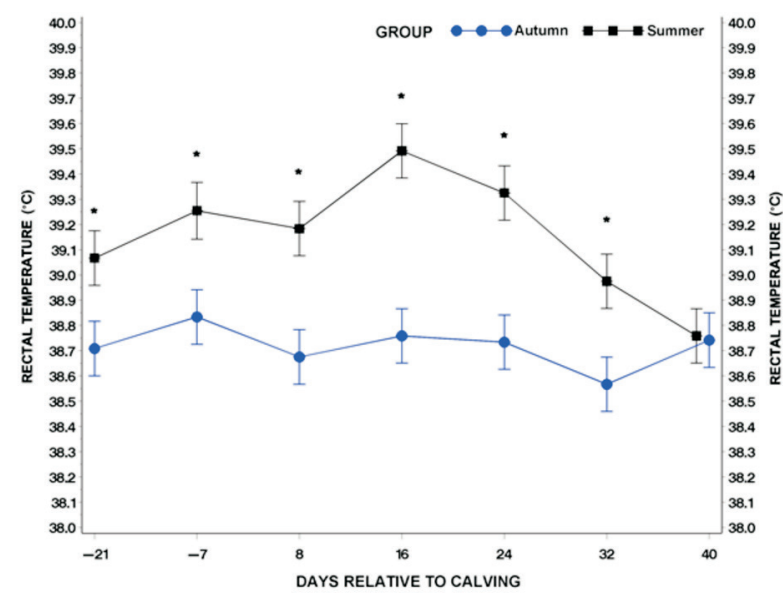

Fig. 1. Rectal temperature $\left({ }^{\circ} \mathrm{C}\right)$ in the autumn and summer groups during the transition period.

*Statistically significant difference between groups $(\mathrm{P}<0.05)$.

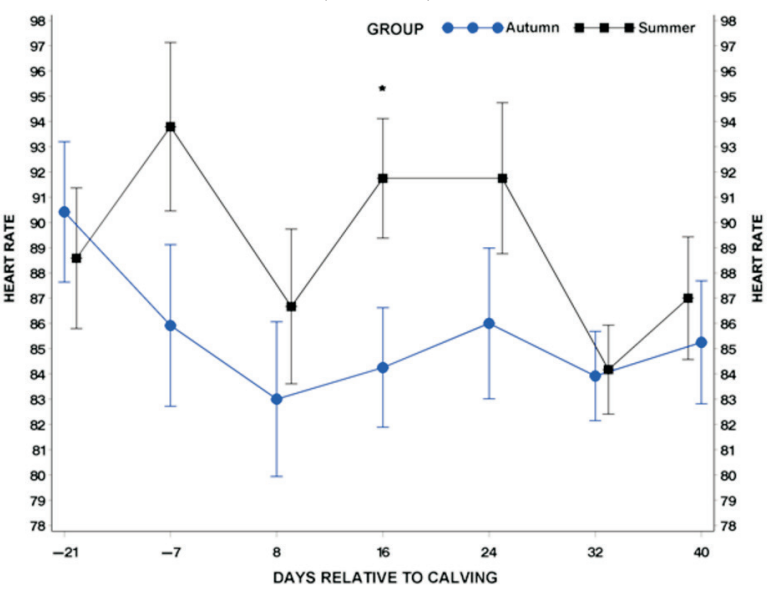

Fig. 3. Heart rate (counts/minute) in the autumn and summer groups during the transition period.

* Statistically significant difference between groups $(\mathrm{P}<0.05)$.

In the autumn group, glucose concentration was significantly decreased after calving $(\mathrm{P}<0.01)$ at days $8,16,24$ and 32 in relation to before calving at day -21 . The summer cows had no differences in glucose concentration during the periparturient period. In addition, there were no significant differences $(\mathrm{P}>0.05)$ between the summer and autumn groups at any sampling point (Fig. 5).

Triglyceride concentration was significantly higher $(\mathrm{P}<0.05)$ at day 32 of lactation $(0.32 \mathrm{mmol} / \mathrm{L})$ in the autumn group compared to the values in the summer group $(0.17 \mathrm{mmol} / \mathrm{L})$. There were no

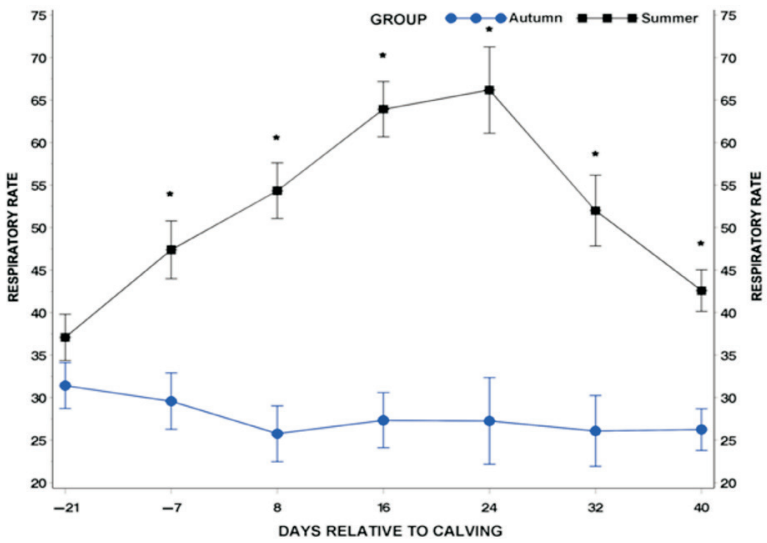

Fig. 2. Respiratory rate (counts/minute) in the autumn and summer groups during the transition period.

*Statistically significant difference between groups $(\mathrm{P}<0.001)$.

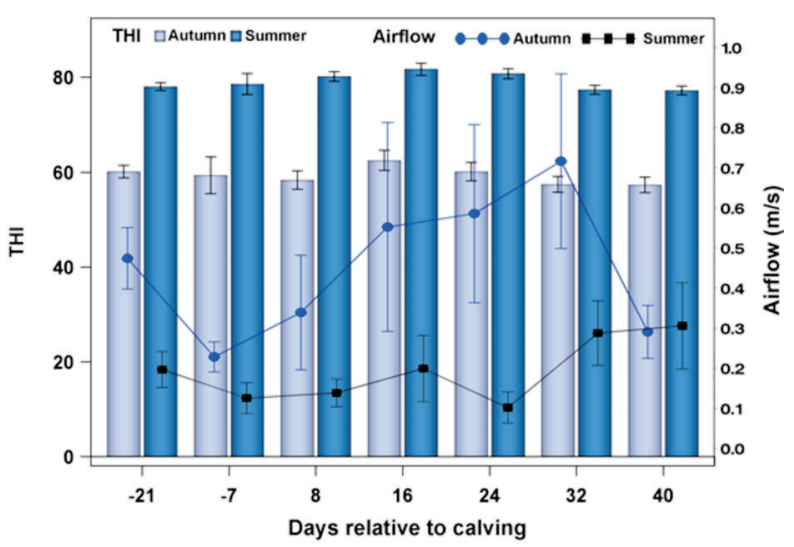

Fig. 4. Temperature-humidity index (THI) and airflow in the autumn and summer groups during the transition period.

significant differences between the two groups at the other sampling points (Fig. 6).

In the autumn group, total cholesterol concentration increased significantly after parturition. It was significantly higher postpartum at days 16, 24, 32 and 40 compared to values before parturition, at days -21 and $-7(\mathrm{P}<0.0001)$. In the summer group, total cholesterol concentration also increased postpartum, being significantly higher at days 24, 32 and 40 postpartum than before parturition at days -21 and $-7(\mathrm{P}<0.0001)$. 


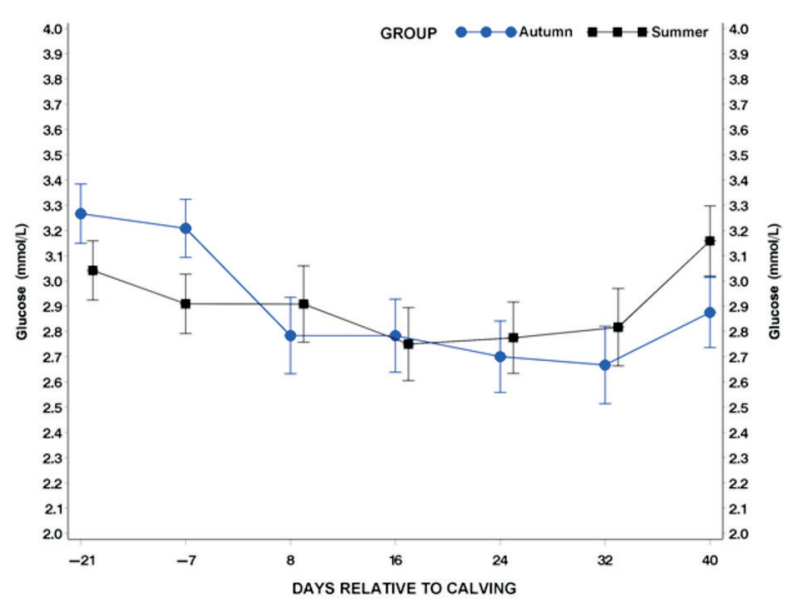

Fig. 5. Glucose concentration ( $\mathrm{mmol} / \mathrm{L})$ in the autumn and summer groups during the transition period.

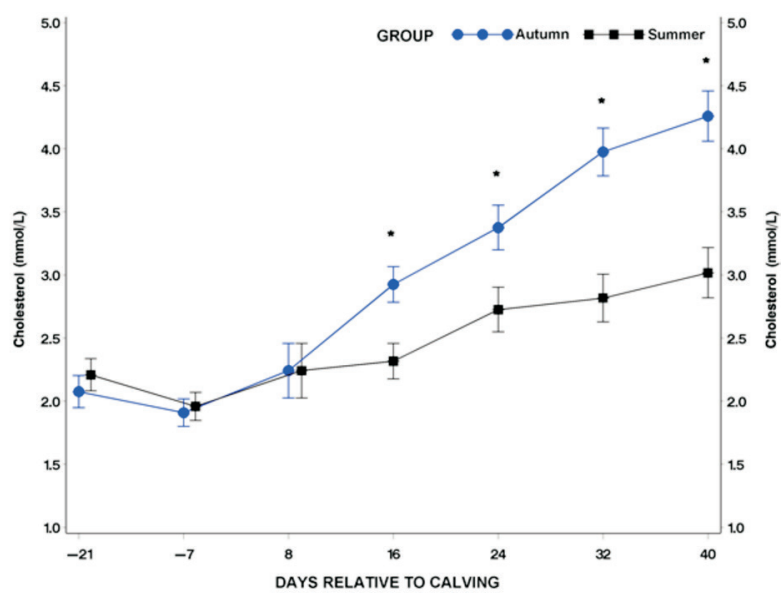

Fig. 7. Total cholesterol concentration $(\mathrm{mmol} / \mathrm{L})$ in the autumn and summer groups during the transition period.

* Statistically significant difference between groups $(\mathrm{P}<0.05)$.

In the summer cows, total cholesterol concentrations were significantly lower after parturition at days 16, 24, 32 and 40 in comparison to the autumn cows at the same sampling points $(\mathrm{P}<0.05)$, Fig. 7).

The concentrations of HDL-cholesterol followed a similar trend, being significantly increased after parturition in both groups compared to values before calving. The summer group had significantly lower HDL-C levels after calving $(\mathrm{P}<0.05)$ at days 16,24 , 32 and 40 than cows during the autumn (Fig. 8).

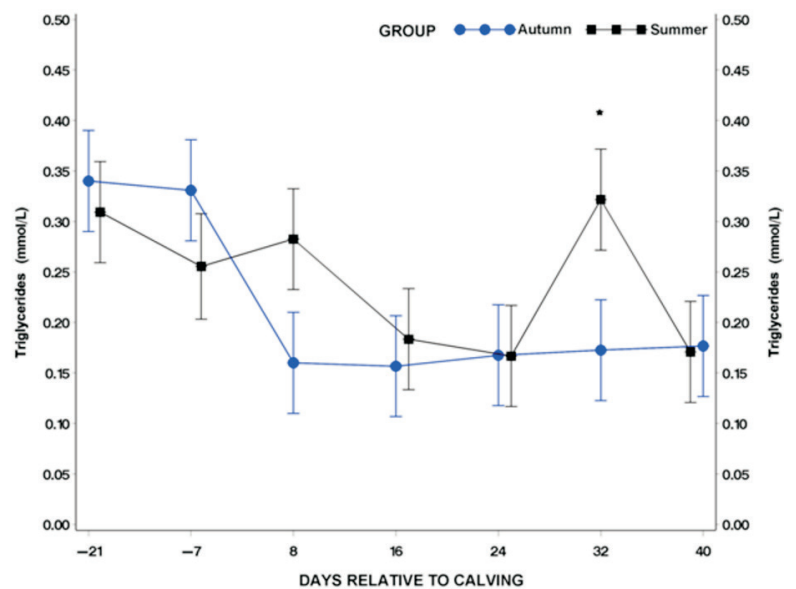

Fig. 6. Triglycerides concentration $(\mathrm{mmol} / \mathrm{L})$ in the autumn and summer groups during the transition period.

*Statistically significant difference between groups

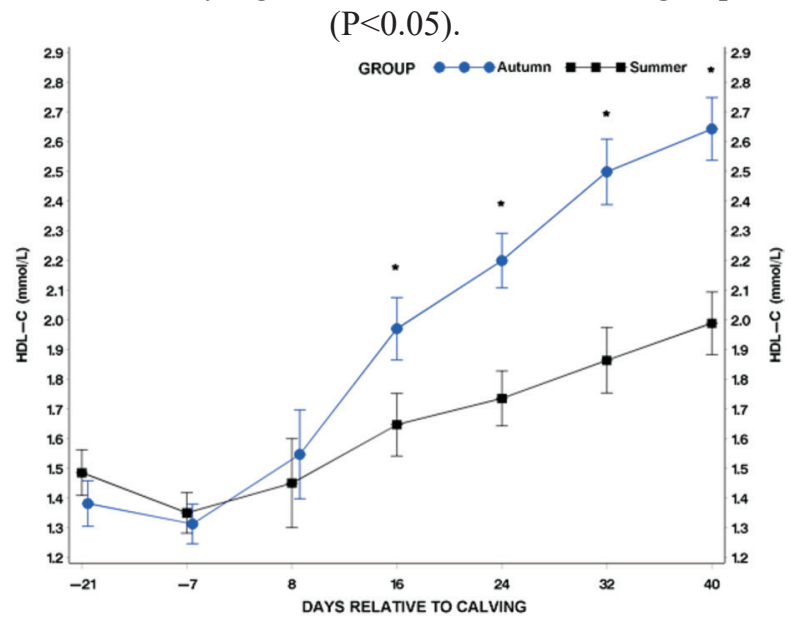

Fig. 8. HDL-cholesterol (HDL-C) concentration $(\mathrm{mmol} / \mathrm{L})$ in the autumn and summer groups during the transition period. *Statistically significant difference between groups $(\mathrm{P}<0.05)$.

In the autumn group, NEFA concentrations were significantly higher in early lactation at days $8,16,24$ and 32 than in late pregnancy at days -21 before calving $(\mathrm{P}<0.001)$. At day 40 of lactation, NEFA levels decreased to the same level as before calving. In the summer group, NEFA concentrations were significantly higher at day -7 before calving $(\mathrm{P}<0.05)$ and at day 8 of lactation $(\mathrm{P}<0.001)$ compared to the values at day -21 before calving. Comparing the investigated groups, NEFA concentrations were significantly higher $(\mathrm{P}<0.05)$ in the summer group before calving at day -7 , while 


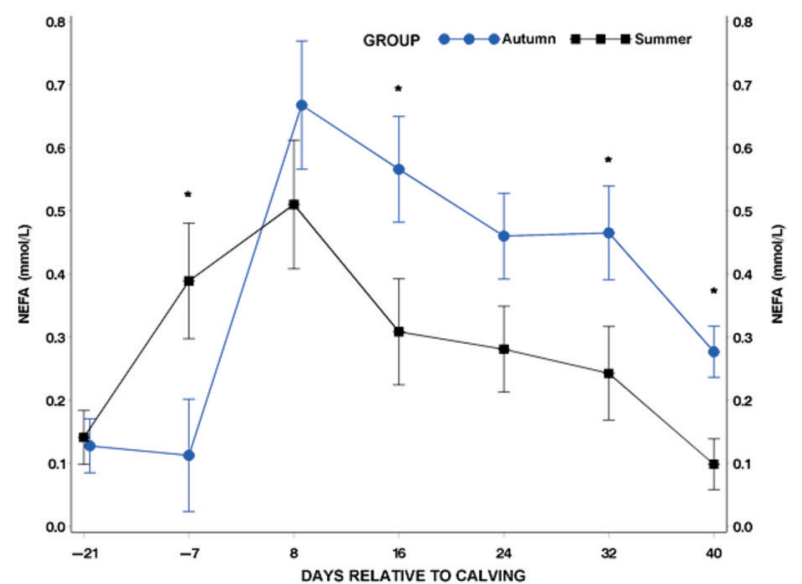

Fig. 9. Nonesterified fatty acid (NEFA) concentration $(\mathrm{mmol} / \mathrm{L})$ in the autumn and summer groups during the transition period. $*$ Statistically significant difference between groups $(\mathrm{P}<0.05)$.

after calving it was significantly lower in cows during the summer $(\mathrm{P}<0.05)$ at days 16 and 32 of lactation (Fig. 9).

During the autumn, BHB concentration was significantly higher $(\mathrm{P}<0.01)$ after calving at days $8,16,24,32$ and 40 of lactation as compared to the value at -21 day before parturition. In the summer group, there were no statistically significant differences between sampling points. The autumn group had higher BHB concentrations after calving compared to the summer cows, with statistical significance $(\mathrm{P}<0.05)$ at days 8,16 and 24 postpartum (Fig. 10).

\section{Discussion}

Dairy cows are susceptible to heat stress, particularly during the transition period, due to the negative energy balance and high metabolic rate from late pregnancy to early lactation $(\mathrm{KOCH}$ et al., 2016). During hot months, dairy cows produce a large amount of metabolic heat and accumulate additional heat from the environment, particularly during lactation. These cause a rise in the cow's body temperature, and consequently a decrease in feed intake, leading to decreased production (WEST, 2003).

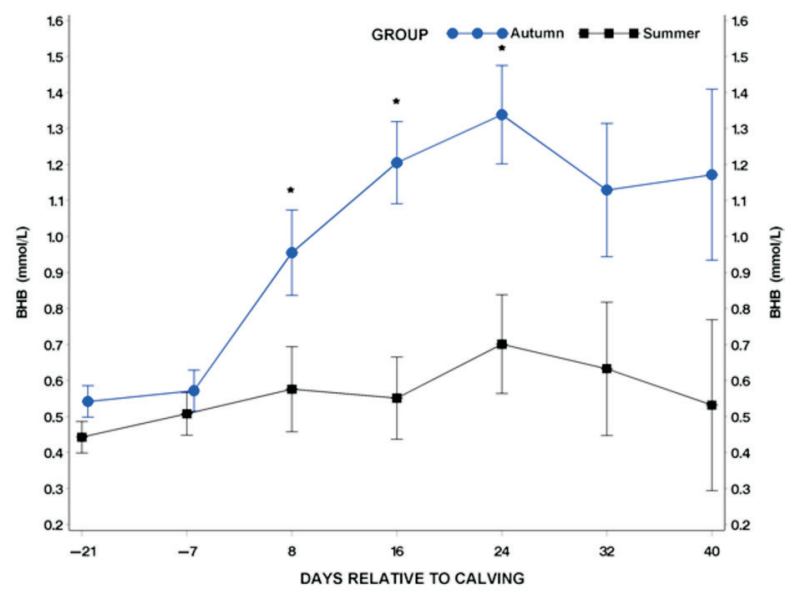

Fig. 10. Betahydroxy-butyrate (BHB) concentration $(\mathrm{mmol} / \mathrm{L})$ in the autumn and summer groups during the transition period. * Statistically significant difference between groups $(\mathrm{P}<0.05)$.

In addition to increased body temperature, cows exposed to high ambient temperature express increased heart and respiratory rates and perspiration in order to achieve homoeothermic conditions (KADZERE et al., 2002; ZÄHNER et al., 2004; AVENDAÑO-REYES et al., 2011). The temperature-humidity index (THI) is a commonly used indicator to estimate the degree of thermal stress, suggesting that a THI above 72 indicates the adverse effect of a hot environment on their physiological state and production (ARMSTRONG, 1994; BERNABUCCI et al., 2010).

In the present study, the cows that were in the transition period during the summer months (June, July, August) had a significantly higher body temperature than cows in the transition period in the autumn, as was also reported in other studies (WHEELOCK et al., 2010; LAMP et al., 2015; MIN et al., 2015). Heart rate was increased in the summer period with statistical significance at $16^{\text {th }}$ day of lactation. In accordance with our study, REJEB et al. (2016) reported increased heart rate under heat stress conditions. On the contrary, COWLEY et al. (2015) and DE ANDRADE FERRAZZA et al. (2017) reported a gradually decreased heart rate. However, these studies were carried out in experimental heat stress conditions, which may explain the disagreement with our results. In the 
current study, the respiratory rate was significantly higher during the periparturient period in the summer than in autumn, which is in accordance with other studies (MIN et al., 2015; BARRERA GARCIA et al., 2015). In addition, the respiratory rate during the summer was higher in our study close to calving, indicating intensive metabolic and hormonal changes in late pregnancy and early lactation. Changes in physiological parameters in heat stress conditions are a result of the adaptive mechanisms of animals aimed at achieving thermal equilibrium.

The transition period is characterised by a dramatic increase in nutrient requirements that demands metabolic adaptation to meet the need for energy in late pregnancy and early lactation, and this often results in a negative energy balance. During hot periods, feed intake in periparturient cows declines by around 50\% (WHEELOCK et al., 2010). The main homeorhetic adaptation of the glucose metabolism during the transition period is an increase in hepatic gluconeogenesis and a parallel decrease in glucose oxidation by peripheral tissues. This adaptation is aimed at providing glucose for foetal needs at the end of pregnancy, and particularly for lactose synthesis by the mammary gland in early lactation (OVERTON and WALDRON, 2004). This postabsorptive metabolism of glucose is a consequence of decreased insulin concentration (BELL, 1995). In our study, thermoneutral cows had a decline in glucose concentration after calving, indicating a negative energy balance and increased requirements for energy in early lactation. Similar results were reported by SEIFI et al. (2007), TURK et al. (2008) and FOLNOŽIĆ et al. (2015). In the summer group, there were no significant differences in glucose concentrations during the transition period. In addition, there were no significant differences in glucose concentrations between the summer and autumn groups. These results are in accordance with DO AMARAL et al. (2009) who did not find any significant differences in glucose concentrations between heat stressed and thermoneutral cows.

A glucose-sparing metabolism, accompanied by low insulin levels during the transition period initiates lipid mobilisation from adipose tissue, with increased NEFA and ketone concentrations in the blood (OVERTON and WALDRON, 2004). In our study, NEFA concentrations significantly increased in the autumn group at the $8^{\text {th }}$ day after calving, while in the summer group, they increased significantly at day -7 before calving and at day 8 after calving, compared to the values at day -21 before parturition, respectively. Similar results were obtained by other studies (SEIFI et al., 2007; TURK et al., 2013 and 2016; FOLNOŽIĆ et al., 2015). Additionally, the summer group had significantly higher NEFA concentration at day -7 before parturition and lower levels at days 16, 32 and 40 after calving, compared with the autumn group. The reasons for the different response in NEFA concentrations before and after calving have been reported by HAHN (1999) and WEST (2003), who suggested that lactating cows are more susceptible to heat stress as they produce more metabolic heat during milk production than non-lactating cows in late pregnancy. Recent studies have also demonstrated lower NEFA concentrations in heat stressed dairy cows (RHOADS et al., 2009; SHWARTZ et al., 2009; WHEELOCK et al., 2010; $\mathrm{KOCH}$ et al., 2016) indicating that heat stressed dairy cows respond differently than what would be expected in cows exposed to decreased energy intake during the transition period. Opposite results were obtained in our previous study (TURK et al., 2015) carried out on heifers, who responded to heat stress with higher NEFA levels during the transition period. Cows exposed to heat stress fail to shift their postabsorptive metabolism into glucosesparing metabolic adaptation (WHEELOCK et al., 2010). They rather increase glucose utilisation by peripheral tissue, that prevents an increase in fatty acid oxidation in order to limit heat production (WHEELOCK et al., 2010; KOCH et al., 2016). This is a surprising mechanism because cows under heat stress have reduced feed intake and this normally stimulates lipid mobilisation from adipose tissue. Homeorhetic mechanisms during heat stress are directed to suppress lipid mobilisation (WHEELOCK et al., 2010) because more metabolic heat is produced by NEFA oxidation than that of carbohydrates (BAUMGARD and RHOADS, 2013). WHEELOCK et al. (2010) also reported increased insulin levels in heat stressed dairy cows, indicating that cows utilise more glucose 
in the peripheral tissue during hot periods than thermoneutral cows.

In line with the decreased NEFA levels in heat stressed cows in our study, BHB concentrations were also decreased in early lactation compared to the autumn group, indicating decreased NEFA oxidation and consequently less production of ketone compounds. Similar results were reported by BARRERA GARCIA et al. (2015) and MOREIRA et al. (2015).

Serum lipid parameters (total cholesterol and HDL-C) were decreased in the summer group after calving compared to the autumn period, in agreement with ABENI et al. (2007), suggesting that cholesterol might be used for cortisol synthesis in heat stress conditions, because heat stressed dairy cows have increased cortisol concentrations in their blood (CALAMARI and BERTONI, 2009).

\section{Conclusion}

Changes in energy metabolism in cows under heat stress are greater in early lactation than in late pregnancy because lactating dairy cows are more susceptible to heat stress than non-lactating cows as metabolic heat production increases with milk synthesis. Dairy cows respond to heat stress in a different way than thermoneutral cows, using a metabolic adaptation that increases gluconeogenesis and glucose utilisation by the peripheral tissues, and decreases NEFA oxidation in order to produce less metabolic heat. These results could contribute to a better understanding of energy metabolism and metabolic adaptation in dairy cows exposed to a hot environment, and to the development of novel strategies to diminish the negative effects of heat stress, and improve animal health, welfare and performance.

\section{Conflicts of interest}

The authors declared that there are no conflicts of interest.

\section{References}

ABENI, F., L. CALAMARI, L. STEFANINI (2007): Metabolic conditions of lactating Friesian cows during the hot season in the Po valley. 1. Blood indicators of heat stress. Int. J. Biometeorol. 52, 87-96. DOI: $10.1007 / \mathrm{s} 00484-007-0098-3$
ARMSTRONG, D. V. (1994): Heat stress interaction with shade and cooling. J. Dairy Sci. 77, 2044-2050.

DOI: $10.3168 /$ jds.s0022-0302(94)77149-6

AVENDAÑO-REYES, L., J. A. HERNÁNDEZ-RIVERA, F. D. ALVAREZ-VALENZUELA, U. MACÍAS-CRUZ, R. DÍAZ-MOLINA, A. CORREA-CALDERÓN, P. H. ROBINSON, J. G. FADEL (2011): Physiological and productive responses of multiparous lactating Holstein cows exposed to short-term cooling during severe summer conditions in an arid region of Mexico. Int. J. Biometeorol. 56, 993-999.

DOI: $10.1007 / \mathrm{s} 00484-011-0510-\mathrm{X}$

BARRERA GARCIA, A., N. ANGELI, L. MACHADO, F. CARDOSO DE CARDOSO, F. GONZALEZ (2015): Relationships between heat stress and metabolic and milk parameters in dairy cows in southern Brazil. Trop. Anim. Health Pro. 47, 889-894.

DOI: $10.1007 / \mathrm{s} 11250-015-0804-9$

BAUMGARD, L. H, R. P. RHOADS (2013): Effects of heat stress on postabsortive metabolism and energetic. Annu. Rev. Anim. Biosci. 1, 311-337.

DOI: 10.1146/annurev-animal-031412-103644

BELL, A. W. (1995): Regulation of organic nutrient metabolism during transition from late pregnancy to early lactation. J. Anim. Sci. 73, 2804-2819.

DOI: $10.2527 / 1995.7392804 x$

BELL, A.W., BAUMAN, D.E. (1997): Adaptations of glucose metabolism during pregnancy and lactation. J. Mammary Gland Biol. Neopl. 2, 265-278.

BERNABUCCI, U., N. LACETERA, L. H. BAUMGARD, R. P. RHOADS, B. RONCHI, A. NARDONE (2010): Metabolic and hormonal acclimation to heat stress in domesticated ruminants. Animal 4, 1167-1183.

DOI: $10.1017 / \mathrm{s} 175173111000090 \mathrm{x}$

CALAMARI, L., G. BERTONI (2009): Model to evaluate welfare in dairy cow farms. Ital. J. Anim. Sci. 8, 301-323. DOI: $10.4081 /$ ijas.2009.s1.301

CHAPINAL, N., M. CARSON, T. F. DUFFIELD, M. CAPEL, S. GODDEN, M. W. OVERTON, J. E., P. SANTOS, S. J. LEBLANC (2011): The association of serum metabolites with clinical disease during the transition period. J. Dairy Sci. 94, 4897-4903.

DOI: $10.3168 /$ jds.2010-4075

COWLEY, F. C., D. G. BARBER, A. V. HOULIHAN, D. P. POPPI (2015): Immediate and residual effects of heat stress and restricted intake on milk protein and casein composition and energy metabolism. J. Dairy Sci. 98, 2356-2368.

DOI: $10.3168 /$ jds.2014-8442 
DE ANDRADE FERRAZZA, R., H. D. MOGOLLÓN GARCIA, V. H. VALLEJO ARISTIZÁBAL, C. DE SOUZA NOGUEIRA, C. J. VERÍSSIMO, J. R. SARTORI, R. SARTORI, J. C. PINHEIRO FERREIRA (2017): Thermoregulatory responses of Holstein cows exposed to experimentally induced heat stress. J. Therm. Biol. 66, 6880.

DOI: $10.1016 /$ j.jtherbio.2017.03.014

DO AMARAL, B. C., E. E. CONNOR, S. TAO, J. HAYEN, J. BUBOLZ, G. E. DAHL (2009): Heat stress abatement during the dry period: does cooling improve transition into lactation? J. Dairy Sci. 92, 5988-5999.

DOI: $10.3168 /$ jds.2009-2343

DRACKLEY, J. K., T. R. OVERTON, G. N. DOUGLAS (2001): Adaptations of glucose and long-chain fatty acid metabolism in liver of dairy cows during the periparturient period. J. Dairy Sci. 84, E100-E112.

DOI: 10.3168/jds.s0022-0302(01)70204-4

FOLNOŽIĆ, I., R. TURK, D. ĐURIČIĆ, S. VINCE, J. PLEADIN, Z. FLEGAR-MEŠTRIĆ, H. VALPOTIĆ, T. DOBRANIĆ, D. GRAČNER, M. SAMARDŽIJA (2015): influence of body condition on serum metabolic indicators of lipid mobilization and oxidative stress in dairy cows during the transition period. Reprod. Domest. Anim. 50, 910-917.

DOI: $10.1111 /$ rda. 12608

GUINARD-FLAMENT, J., E. DELAMAIRE, S. LEMOSQUET, M. BOUTINAUD, Y. DAVID (2006): Changes in mammary uptake and metabolic fate of glucose with oncedaily milking and feed restriction in dairy cows. Reprod. Nutr. Dev. 46, 589-598.

DOI: $10.1051 /$ rnd:2006030

HAHN, G. L. (1999): Dynamic responses of cattle to thermal heat loads. J. Anim. Sci. 77, 10-20.

DOI: $10.2527 / 1997.77$ suppl_210x

KADZERE, C. T., M. R. MURPHY, N. SILANIKOVE, E. MALTZ (2002): Heat stress in lactating dairy cows: a review. Livest. Prod. Sci. 77, 59-91.

DOI: 10.1016/s0301-6226(01)00330-X

$\mathrm{KOCH}, \mathrm{F}, \mathrm{O}$. LAMP, M. ESLAMIZAD, J. WEITZEL, B. KUHLA (2016): Metabolic response to heat stress in latepregnant and early lactation dairy cows: implications to liver-muscle crosstalk. PLOS One 11, e0160912.

DOI: 10.1371/journal.pone.0160912

LAMP, O., M. DERNO, W. OTTEN, M. MIELENZ, G. NURNBERG, B. KUHLA (2015): Metabolic heat stress adaption in transition cows: differences in macronutrient oxidation between late-gestating and early-lactating German Golstein dairy cows. PLOS One 10, e0125264.

DOI: 10.1371/journal.pone.0125264

MARCO-RAMELL, A., A. M. DE ALMEIDA, S. CRISTOBAL, P. RODRIGUES, P. RONCADA, A. BASSOLS (2016): Proteomics and the search for welfare and stress biomarkers in animal production in the onehealth context. Mol. BioSyst. 12, 2024-2035.

DOI: $10.1039 / \mathrm{c} 5 \mathrm{mb} 00788 \mathrm{~g}$

MIN, L., J. CHENG, B. SHI, H. YANG, N. ZHENG, J. WANG (2015): Effects of heat stress on serum insulin, adipokines, AMP-activated protein kinase, and heat shock signal molecules in dairy cows. J. Zhejiang Univ-Sc. B. 16, 541548.

DOI: $10.1631 /$ jzus.b1400341

MOREIRA, T. F., E. J. FACURY FILHO, R. M. MENESES, F .L. M. MENDONCA, J. A. M. LIMA, A. U. CARVALHO (2015): Energetic status of crossbreed dairy cows during transition period in two different seasons. Arq. Bras. Med. Vet. Zoo. 67.

DOI: $10.1590 / 1678-4162-8287$

NRC (NATIONAL RESEARCH COUNCIL) (1971): A guide to environmental research on animals. Natl. Acad. Sci., Washington, DC.

OVERTON, T.R., M.R.WALDRON (2004): Nutritional management of transition dairy cows: strategies to optimize metabolic health. J. Dairy Sci. 87, E105-E119.

DOI: $10.3168 /$ jds.s0022-0302(04)70066-1

REJEB, M., R. SADRAOUI, T. NAJAR, M. BEN M'RAD (2016): A complex interrelationship between rectal temperature and dairy cows' performance under heat stress conditions. Open J. Anim. Sci. 6, 24-30.

DOI: 10.4236/ojas.2016.61004

REYNOLDS, C.K., P.C. AIKMAN, B. LUPOLI, D.J. HUMPHRIES, D.E. BEEVER (2003): Splanchnic metabolism of dairy cows during the transition from late gestation through early lactation. J. Dairy Sci. 86, 12011217.

DOI: $10.3168 /$ jds.s0022-0302(03)73704-7

RHOADS, M. L., R. P. RHOADS, M. J. VAN BAALE, R. J. COLLIER, S. R. SANDERS, W. J. WEBER, B. A. CROOKER, L. H. BAUMGARD (2009): Effects of heat stress and plane of nutrition on lactating Holstein cows: 1. Production, metabolism, and aspects of circulating somatotropin. J. Dairy Sci. 92, 1986-1997.

DOI: $10.3168 /$ jds.2008-1641

SEIFI, H. A., M. GORJI-DOOZ, M. MOHRI, B. DALIRNAGHADEH, N. FARZANEH (2007): Variations of energy-related biochemical metabolites during transition period in dairy cows. Comp. Clin. Pathol. 16, 253-258.

DOI: 10.1007/s00580-007-0682-2

SHWARTZ, G., M. L. RHOADS, M. J. VANBAALE, R. P. RHOADS, L. H. BAUMGARD (2009): Effects of a supplemental yeast culture on heat-stressed lactating Holstein cows. J. Dairy Sci. 92, 935-942.

DOI: $10.3168 /$ jds.2008-1496

TURK, R., D. JURETIĆ, D. GEREŠ, A. SVETINA, N. TURK, Z. FLEGAR-MEŠTRIĆ (2008): Influence of oxidative stress and metabolic adaptation on PON1 activity and 
MDA level in transition dairy cows. Anim. Reprod. Sci. 108, 98-106.

DOI: 10.1016/j.anireprosci.2007.07.012

TURK, R., O. PODPEČAN, J. MRKUN, M. KOSEC, Z. FLEGAR-MEŠTRIĆ, S. PERKOV, J. STARIČ, M. ROBIĆ, M. BELIĆ, P. ZRIMŠEK (2013): Lipid mobilisation and oxidative stress as metabolic adaptation processes in dairy heifers during transition period. Anim. Reprod. Sci. 141, 109-115.

DOI: 10.1016/j.anireprosci.2013.07.014

TURK, R., O. PODPEČAN, J. MRKUN, Z. FLEGARMEŠTRIĆ, S. PERKOV, P. ZRIMŠEK (2015): The effect of seasonal thermal stress on lipid mobilisation, antioxidant status and reproductive performance in dairy cows. Reprod. Domest. Anim. 50, 595-603.

DOI: $10.1111 /$ rda. 12534

TURK, R., I. FOLNOŽIĆ, D. ĐURIČIĆ, S. VINCE, Z. FLEGAR-MEŠTRIĆ, T. DOBRANIĆ, H. VALPOTIĆ, M. SAMARDŽIJA (2016): Relationship between paraoxonase-1 activity and lipid mobilisation in transition dairy cows. Vet. arhiv 86, 601-612.
WEST, J. W. (2003): Effects of heat-stress on production in dairy cattle. J. Dairy Sci. 86, 2131-2144.

DOI: $10.3168 /$ jds.s0022-0302(03)73803-x

WHEELOCK, J. B., R. P. RHOADS, M. J. VANBAALE, S. R. SANDERS, L. H. BAUMGARD (2010): Effects of heat stress on energetic metabolism in lactating Holsteincows. J. Dairy Sci. 93, 644-655.

DOI: $10.3168 /$ jds.2009-2295

ZÄHNER, M., L. SCHRADER, R. HAUSER, M. KECK, W. LANGHANS, B. WECHSLER (2004): The influence of climatic conditions on physiological and behavioural parameters in dairy cows kept in open stables. Anim. Sci. 78, 139-147.

DOI: $10.1017 / \mathrm{s} 1357729800053923$

Received: 28 October 2019

Accepted: 20 November 2019

TURK, R., N. ROŠIĆ, S. VINCE, S. PERKOV, M. SAMARDŽIJA, B. BEER-LJUBIĆ, M. BELIĆ, M. ROBIĆ: Utjecaj toplinskog stresa na energetski metabolizam u krava simentalske pasmine tijekom peripartalnog razdoblja. Vet. arhiv 90, 1-10, 2020.

\section{SAŽETAK}

Cilj ovog rada bio je istražiti energetski metabolizam mliječnih krava pod utjecajem toplinskog stresa u prijelaznom razdoblju. U istraživanje su uključene 24 mliječne krave simentalske pasmine koje su podijeljene u dvije skupine: krave s terminom teljenja tijekom ljeta $(n=12)$ i krave s terminom teljenja tijekom jeseni $(n=12)$. Mjereni su fiziološki pokazatelji (rektalna temperatura, vrijednosti bila i frekvencija disanja) te metabolički pokazatelji u serumu (glukoza, trigliceridi, ukupni kolesterol, HDL kolesterol (HDL-C), slobodne masne kiseline (NEFA) i betahidroksibutirat (BHB), i to 21 i 7 dana prije teljenja te 8, 16, 24, 32 i 40 dana nakon teljenja. Koncentracija glukoze nije bila statistički znakovito različita između istraživanih skupina $(\mathrm{P}>0,05)$. Koncentracija NEFA-e bila je statistički znakovito veća $(\mathrm{P}<0,05)$ u ljetnoj skupini 7 dana prije teljenja, dok je 16 i 32 dana nakon teljenja bila znakovito manja $(\mathrm{P}<0,05)$ u usporedbi s jesenskom skupinom. U ljetnoj je skupini koncentracija BHB bila manja nakon teljenja u odnosu na jesensko razdoblje, sa statističkom znakovitošću 8., 16. i 24. dan laktacije $(\mathrm{P}<0,05)$. Lipidni pokazatelji (ukupni kolesterol i HDL-C) također su bili znakovito manji $(\mathrm{P}<0,05)$ u ljetnoj skupini nakon teljenja u usporedbi $\mathrm{s}$ jesenskom skupinom. Rezultati pokazuju da su promjene u energetskom metabolizmu mliječnih krava pod utjecajem toplinskog stresa usmjerene na smanjenje oksidacije slobodnih masnih kiselina, kako bi se smanjila proizvodnja metaboličke topline. Ova se metabolička prilagodba pojavljuje većinom nakon teljenja jer su mliječne krave mnogo osjetljivije na toplinski stres u ranoj laktaciji budući da se tijekom proizvodnje mlijeka stvara više metaboličke topline nego u kasnoj gravidnosti tijekom suhostaja.

Ključne riječi: toplinski stres; mliječne krave; lipidna mobilizacija; slobodne masne kiseline; beta-hidroksibutirat 